\title{
Veil of Ignorance Rules in Constitutional Law
}

\author{
Adrian Vermeule ${ }^{\dagger}$
}

A veil of ignorance rule (more briefly a "veil rule") is a rule that suppresses self-interested behavior on the part of decisionmakers; it does so by subjecting the decisionmakers to uncertainty about the distribution of benefits and burdens that will result from a decision.' A veil rule may produce this distributive uncertainty by either of two methods. One method is to place decisionmakers under a constraint of ignorance about their own identities and attributes. John Rawls coined the phrase "veil of ignorance" to describe a hypothetical original position in which principles of justice are chosen under precisely this constraint. ${ }^{2}$ But that is a special case of veil rules generally, indeed a radical case. Rawls's thought experiment introduces uncertainty by allowing the decisionmaker to know the distributive consequences of a decision on future citizens - call them $A$ and $B$-but denying the decisionmaker the knowledge of whether she herself will occupy $A$ 's position or $B$ 's position. Where veil of ignorance rules appear under historical rather than hypothetical conditions, however, the relevant decisionmakers will usually know their own identities and interests. Veil rules that appear in actual constitutions, then, more often adopt a second method for introducing uncertainty: Although the decisionmaker knows or can guess whether she will occupy $A$ 's or $B$ 's position, the rule introduces uncertainty about whether $A$ or $B$ will reap the greater gains from the decision. ${ }^{3}$

† Professor of Law, The University of Chicago. Thanks to Elizabeth Garrett, Jack Goldsmith, Saul Levmore, Eric Posner, David Strauss, Cass Sunstein, and David Weisbach for helpful comments, and thanks to Jamil Jaffer for excellent research assistance. Special thanks to Yun Soo Vermeule.

1. For a simple example, consider a rule that requires an official with regulatory authority over the stock market to place her assets in a "blind trust." Even if the official is self-interested, she will be uncertain whether any given decision will increase or decrease the value of her portfolio. She will thus be unable to skew her decisions in order to promote her personal interests. Other homely examples are blind grading and the practice by which orchestras place auditioners behind a screen.

2. JOHN RAWLS, A THEORY OF JUSTICE 118-23 (rev. ed. 1999).

3. An intermediate case occurs when a decisionmaker faces a decision that will principally affect not the decisionmaker herself, but her (genetic) descendants. If the time horizon over which the decision will matter is long enough, the attributes of descendants may be so difficult to predict that the decisionmaker will effectively bc left ignorant of the identity of the persons whose interests she would favor, if she could. In this vein, participants at the Constitutional Convention 
By speaking of veil rules in constitutions, I mean to pose a very different question than the one pursued in the standard discussions of the veil of ignorance. The constitutional choice literature stemming from James Buchanan, Gordon Tullock, and their successors conceives the uncertainty produced by the veil of ignorance as a mechanism for inducing hypothetical constitutional designers to approach the choice of the constitutional rules themselves in an impartial way. ${ }^{4}$ Decisionmaking by legislators and other officials within the framework of the constitutional rules, by contrast, falls in the domain of "ordinary politics," where self-interested individuals and factions struggle for advantage. The constitutional designers' self-interest is constrained by uncertainty; that of ordinary decisionmakers is constrained by voting rules (such as supermajority requirements), by substantive constitutional prohibitions on inefficient legislation, and by institutional competition resulting from the separation of powers. I erase that distinction by asking whether and how constitutional rules might subject in-system decisionmakers to the same uncertainty constraint that governs the hypothetical stage of constitutional choice, and for similar reasons. I also touch upon an important special case, the proposal of constitutional amendments, that shares features of both constitutional choice and ordinary politics.

I argue that the Federal Constitution itself contains a number of rules that may usefully be analyzed as veil rules. Provisions, structures, and practices as diverse as the Ex Post Facto and Bill of Attainder Clauses, ${ }^{5}$ the Emoluments Clause, ${ }^{6}$ the Twenty-Seventh Amendment, ${ }^{7}$ Article V's procedures for constitutional amendment, ${ }^{8}$ the doctrine of precedent, the original mechanism for selecting senators (by vote of the state legislatures), ${ }^{9}$ and the rules governing presidential election and succession ${ }^{10}$

argued that the Framers should impartially assess the interests of social classes, and of large and small states, because posterity would distribute their descendants throughout the strata and regions of society. See infra notes 55-56 and accompanying text.

4. See Geoffrey BREnNAN \& JAMES M. BuchanAN, THE REASON OF Rules 28-31 (1985); JAMES M. BuCHANAN \& GoRdon Tullock, THE Calculus of CONSENT 77-80 (1962); DENNiS MUELlER, CONSTITUTIONAL DEMOCRACY 61-64 (1996).

5. U.S. CONST. art. I, $\S 9$, cl. 3 ("No Bill of Attainder or ex post facto Law shall be passed [by Congress]."); id. art. I, $\$ 10$, cl. 1 ("No State shall ... pass any Bill of Attainder [or] ex post facto Law ....").

6. Id. art. I, $\$ 6$, cl. 2 ("No Senator or Representative shall, during the Time for which he was elected, be appointed to any civil Office under the Authority of the United States, which shall have been created, or the Emoluments whereof shall have been encreased during such time....").

7. Id. amend. XXVII ("No Law, varying the compensation for the services of the Senators and Representatives, shall take effect, until an election of Representatives shall have intervened.").

8. Id. art. $\mathrm{V}$ (specifying procedures for constitutional amendment).

9. Id art. I, $\$ 3$, cl. 1 (stating that federal senators shall be chosen by the state legislatures), amended by id. amend. XVII (replacing legislative selection with direct election). 
may all profitably be considered in this light, although not all of these should count as examples of veil rules rightly understood. The legal literature on these and other topics makes casual references to the veil of ignorance, but there has been very little sustained examination of the subject of veil rules as a general strategy for promoting impartial decisions under actual constitutions. " My initial aim, then, is to synthesize and critique these localized literatures in order to obtain an overview of a recurring theme in constitutional design.

The payoff from this synthesizing work is that it helps supply an answer to two questions: why the Constitution does not contain more veil rules than it actually does, and why it uses veil rules where it does use them, but not elsewhere. It sounds paradoxical to move from an explication of existing veil rules in some settings to an explanation for their conspicuous absence in others, but that question illuminates the tradeoffs inherent in constitutional design. Having appreciated the power of veil rules to dampen self-interest, we might want to know why the veil technique is not ubiquitous in the Constitution. In particular, it is a striking feature of constitutional law that Congress is subject to more constitutional veil rules, of wider scope, than is the President or the judiciary. Why should that be so, given that it would be perfectly possible to apply a range of veil rules to the latter institutions as well?

Some of the literature suggests that the skewed distribution of constitutional veil rules is best explained by the presence or absence of alternative institutional features that suppress self-interested decisionmaking. Federal judges, for example, are not restricted by veil rules requiring prospective and general decisionmaking because life tenure and the design of the adjudicative process independently serve to suppress the decisional bias that veil rules are used to check. While this view gives a plausible account of the paucity of veil rules governing judicial action, its logic suggests that the executive branch should be subject to a far more stringent set of veil rules than it actually is. A second type of explanation applies the insight that the price of reducing bias is to reduce

10. Id. art. II, $\S 1$, cls. 3,5 (providing rules for presidential election and succession); id. amend. XII (providing rules for presidential election); $i d$. amends. XX, XXV (providing rules for presidential succession).

11. The most sustained discussion in the law review literature is an excellent short treatment of the veil of ignorance in Michael A. Fitts, Can Ignorance Be Bliss? Imperfect Information as a Positive Influence in Political Institutions, 88 MICH. L. REV. 917, 966-77 (1990). Fitts's emphasis, however, is on the veil effects arising from competition between political parties in a system of separated powers, rather than the sort of textual and doctrinal analysis I offer here. Another related idea is Cass Sunstein's argument that impartiality should be understood to ban decisions that cmbody "naked preferences." CaSs R. SUNSTEIN, THE PARTIAL CONSTITUTION 17-39 (1993). Constitutional rules that instantiate such a ban, however, are not (or, not necessarily) veil rules that regulate decisionmakers' information. They are more often direct restrictions on constitutionally disfavored outcomes. 
decisionmakers' information. ${ }^{12}$ In some settings, the information suppressed by a veil rule is so valuable that its loss might be thought to outweigh even large gains in decisionmaker neutrality. This is true and important, and I shall have recourse to it more than once in explaining the detailed scope of particular veil rules. But paradoxically, the insight is too powerful to be really useful. Any distribution of veil rules across the Constitution, even a distribution much different than the one we see, could be explained by supposing that the costs of foregone information are (or are not) excessive in settings where veil rules do not (or do) apply.

I emphasize a third and somewhat different explanation, one that points not to the direct effects of veil rules but to their secondary or indirect consequences. The indirect tradeoff, I argue, is not between information and neutrality, but between information and motivation, or (as the Framers would have put it) institutional "energy." Veil rules not only dampen both information and bias; they also suppress decisionmakers' activity. Removing the spur of self-interest threatens to reduce decisionmakers' activity below acceptable levels, to the point where constitutional designers might plausibly prefer to lift the veil and spur more activity, even if the price is that some fraction of that increased activity is self-regarding. If, like the Framers, we systematically fear excessive congressional activity, on the one hand, and fear insufficient presidential (and even judicial) activity, on the other hand, then something roughly like the current skewed distribution of veil rules suggests itself. The enervating effect of veil rules would amount to a qualified good in the legislative setting and a qualified bad in executive and judicial settings. This is an interpretive explanation or justification of the Constitution and its implicit theoretical commitments. I make no normative claims about how a new constitution should be designed from scratch, nor do I attempt historical analysis of the later development of federal political institutions, such as the (relative) growth of presidential power.

The plan of the Essay is as follows. Part I defines terms, distinguishes veil rules from the separation of powers and other types of constitutional rules that restrict self-interested decisionmaking, and sets out a few methodological premises. Part II surveys constitutional veil rules by examining "veil tactics" : features of constitutional provisions and doctrines that produce veil-like effects. Examples are constitutional requirements that official decisions be prospective and general, such as the Ex Post Facto and

12. See Saul Levmore, Efficiency and Conspiracy: Conflicts of Interest, Anti-Nepotism Rules, and Separation Strategies, 66 FORDHAM L. REV. 2099 (1998) (analyzing the tradeoff between information and neutrality in conflict-of-interest law); see also Fitts, supra note 11, at 970 (noting that the veil of ignorance is "overinclusive" if "too much information is eliminated"); Elizabeth Garrett, Rethinking the Structures of Decisionmaking in the Federal Budget Process, 35 HARV. J. ON LEGIS. 387, 409-15 (1998) (analyzing the information-bias tradeoff in the context of the federal budget process). 
Bill of Attainder Clauses, and constitutional rules that increase the durability of decisions or delay their effective date, such as the doctrine of precedent in constitutional cases, the Twenty-Seventh Amendment, and the Emoluments Clause. I also touch on the (infrequent) use of randomization in constitutional law. Part III examines the direct effects of veil rules on decisionmakers' information and their indirect effects on decisionmakers' motivation, emphasizing that the enervating effect of veil rules helps us toward an account, or a rationalization, of the distribution of veil rules across institutions. Part IV is a brief conclusion.

\section{DEFINITIONS AND PRELIMINARIES}

\section{A. Self-Interested Decisionmaking and Two Strategies of Constitutional Design}

The point of a veil rule is to prevent self-interested decisionmaking. Constitutional framers may plausibly fear that a decisionmaker who knows both her own identity and the distribution of future benefits and burdens that results from a decision will systematically favor her own interests, in ways detrimental to the quality of the decision. ${ }^{13}$ Mechanisms such as selfserving bias $^{14}$ and the proclivity to engage in motivated reasoning ${ }^{15}$ underpin this concern. Behind the veil, however, the decisionmaker afflicted with uncertainty will, for lack of ex post information about whose interests to favor, choose the option or rule that impartially promotes the good of all those affected in an ex ante sense. The dearth of information produces decisions that mimic those an impartially motivated decisionmaker would produce.

What constitutes "impartial" decisionmaking-the undistorted baseline from which to measure self-interested decisionmaking and suppress it by constitutional rules-is a more difficult question in political theory than in constitutional law, simply because the ambitions of constitutional law are far more modest. The constitutional choice literature debates whether decisionmakers in Rawls's original position would or should choose rules

13. I shall subsume within the category of self-interest a partial preference for decisionmakers' relatives, descendants, political allies, and so forth. The justification for this treatment derives from the modesty of constitutional law's ambitions and the crudity of its instruments. Although there may be conceptual reasons for treating these categories differently, constitutional rules are not usually fine-grained enough to take such differences into account.

14. See Linda Babcock \& George Loewenstein, Explaining Bargaining Impasse: The Role of Self-Serving Biases, J. ECON. PERSP., Winter 1997, at 109, 111 (observing that self-serving bias causes decisionmakers to "arrive at judgments of what is fair or right that are biased in the direction of their own self-interests").

15. See Christopher H. Schroeder \& Robert L. Glicksman, Chevron, State Farm, and EPA in the Court of Appeals During the 1990s, [2001] 31 Envtl. L. Rep. (Envtl. L. Inst.) 10,371 (explaining "motivated reasoning"). 
to maximize average utility or total utility; ${ }^{16}$ should instead select a "maximin" criterion that works to the benefit of the least-well-off, as Rawls advocates; ${ }^{17}$ or should implement some less formal interpretation of impartiality, such as decisionmaking that displays "equal concern and respect" for all parties. ${ }^{18}$ From the standpoint of constitutional design under historical circumstances, however, the alternatives are much less refined. The aim of real-world veil rules is simply to suppress the crudest instances of self-dealing and factional oppression-decisions that would be excluded on any plausibly impartial criterion for public choice, such as the retroactive punishment of political enemies, bills of attainder, or official self-dealing with regard to salaries and emoluments. Disagreement about the uniquely best definition of impartiality need not prove an embarrassment to the limited ambitions of real-world constitutionalism, which are fully satisfied by identifying a set of decisions that all competing definitions of impartiality condemn.

The use of veil rules is not the principal means by which the Constitution constrains self-interested decisionmaking. The Framers' simple theory of action held that decisions are the product of motives and opportunities, and described the principal motives as reason, interest, and passion. ${ }^{19}$ The theory suggests two different strategies for constraining the operation of self-interest. The first is to replace decisionmakers' selfinterested motives with the motive of impartial rationality, thus striking at the problem at its source. Veil rules aim to accomplish that end by interfering with decisionmakers' information, introducing uncertainty about the distribution of benefits and burdens, which forces the self-interested decisionmaker to proceed in an impartially rational way.

Madison, however, argued in The Federalist No. 10 that suppressing self-interest at its source is infeasible. The aim of "giving to every citizen the same opinions, the same passions, and the same interests" - precisely

16. John Harsanyi, for example, advocates a utilitarian account of choice in the original position and uses an "equiprobability postulate" that maximizes the mean utility level of all individuals in society. John C. Harsanyi, Morality and the Theory of Rational Behaviour, in UTILITARIANISM AND BEYOND 39, 44-46 (Amartya Sen \& Bernard Williams eds., 1982).

17. The maximin criterion instructs decisionmakers to choose, from among possible actions, the one whose worst possible consequences are better than the worst possible consequences of the alternative actions. See R. DUNCAN LUCE \& HowaRd RAIFFA, GAMES AND DECISIONS 278 (1957). Rawls uses the maximin criterion to derive his "difference principle," which says that allocative inequalities are permissible only to the extent they maximize the position of the leastwell-off. RAWLS, supra note 2, at 132-35.

18. RONALD DWORKIN, TAKING RIGHTS SERIOUSLY 272-78 (1978).

19. See MORTON White, PHILOSOPHY, THE FEDERALIST, AND THE CONSTITUTION 102-28 (1987). In the present analysis, I will ignore the role of passion. Attempts by constitutional designers to prevent in-system decisionmakers from falling prey to their temporary passions is the subject of the theory of constitutional precommitments, a subject that has been thoroughly studied of late. See, e.g., JON ELSTER, ULYSSES UNBOUND 88.167 (2000); Jeremy Waldron, Precomnitment and Disagreement, in CONSTITUTIONALISM: PHILOSOPHICAL FOUNDATIONS 271 (Larry Alexander ed., 1998). 
what a veil strategy does in an ex ante sense, not by enforcing homogeneity in fact but by reducing decisionmakers' information-Madison rejected out of hand as an "impracticable" method for suppressing self-interested factions. ${ }^{20} \mathrm{He}$ therefore preferred a second strategy to constrain selfinterest: leaving self-interested motives in place while constricting the opportunities available to self-interested decisionmakers. The "policy of supplying, by opposite and rival interests, the defect of better motives" ${ }^{21}$ is to parcel out decisions among different officials and institutions with different self-interested agendas, in the hope that competition among institutions will block self-interested action by any one of them. This is just the separation of powers, which controls the effects rather than the causes of self-interest by ensuring that ambition is made to counteract ambition across institutions.

Madison did not wholly carry the day; existing constitutional veil rules are precisely the sort of "parchment barrier" that he rejected in favor of institutional competition. ${ }^{22}$ Nonetheless, it is fair to say that the baseline constitutional strategy for suppressing self-interested decisionmaking is the separation of powers, and that the use of veil rules is a supplemental and exceptional strategy. My concern in Parts II and III is to say something about where and why the Constitution uses, or declines to use, veil rules as supplements to the normal baseline.

\section{B. Veil Rules and Conflict-of-Interest Rules}

Veil rules must be distinguished from other types of rules that also aim to launder decisionmakers' motivations. Veil rules share a family resemblance with rules that forbid conflicts of interest. A constitutional example is the due process rule that forbids judges from deciding cases in which they have a financial stake. ${ }^{23}$ Yet the two types of rules pursue similar ends by nearly opposite means. A veil rule suppresses selfinterested decisionmaking by introducing uncertainty about who the beneficiary of a decision will be. Conflict rules, roughly speaking, proceed by making the decisionmaker certain that he will not be the beneficiary. The strategy is not to obscure whether $A$ or $B$ will benefit from a decision made by $A$, but rather to tell a given decisionmaker $C$ that, regardless of whether $A$ or $B$ will benefit, $C$ will not. $C$ knows which decision will benefit himself, but the conflict rule removes that decision from the feasible set.

20. The Federalist No. 10, at 123 (James Madison) (Isaac Kramnick ed., 1987).

21. THE FEDERALIST No. 51, supra note 20, at 320 (James Madison).

22. THE FEDERALIST No. 48, supra note 20, at 309 (James Madison).

23. See Tumey v. Ohio, 273 U.S. 510 (1927) (holding that due process is violated when the adjudicator has a financial stake in the outcome). 
The category of conflict-of-interest rules itself breaks down into eligibility rules and recusal rules. Eligibility rules make the decisionmaker ineligible for a benefit, such as an official post, when the relevant decisions will affect the existence or extent of the benefit. A simple example is the Incompatibility Clause, which bars sitting members of Congress from serving in either the executive or judicial branch ${ }^{24}$ Legislators know that a vote to expand the powers or raise the salary of a nonlegislative office will not bring them direct, personal benefits while they retain their legislative seats. ${ }^{25}$ In a similar vein, the French Constituent Assembly of 1791, charged with drafting a new constitution, adopted Robespierre's suggestion for a "self-denying ordinance": Its members voted to make themselves ineligible for election to the first ordinary legislature to be assembled under the new constitution. ${ }^{26}$ The concern was that the drafters, anticipating their election to the soon-to-be-constituted legislature, would grant it unduly broad powers, and the self-denying ordinance told the drafters that they at least would not benefit from doing so. A veil rule would have introduced additional uncertainty, over and above the ever-present uncertainties of politics, about whether the drafters would gain places in the new legislature. The most obvious such rule, however, would be to provide that selection to the new legislature be made randomly, and I subsequently discuss the extreme aversion to random selection of officials in constitutional law.

A substitute for, or alternative to, eligibility rules is recusal rules, which replace the decisionmaker altogether when the costs of replacement are low and the costs of an eligibility rule or a veil rule are high. Recusal rules are conflict rules because they replace a biased decisionmaker with a decisionmaker who knows he cannot skew the decision to his own benefit. ${ }^{27}$ When the Senate tries the President on a bill of impeachment it is the Chief Justice, rather than the Vice President, who presides, for fear that an ambitious Vice President would otherwise skew the proceedings against the defendant in order to succeed to his office. ${ }^{28}$ The eligibility-based alternative-to prohibit the Vice President from succeeding a convicted President over whose impeachment trial he had presided-would require

24. U.S. CONST, art. I, \& 6, cl. 2 ("[N]o Person holding any Office under the United States, shall be a Member of either House during his Continuance in Office.").

25. The corollary problem of legislators who give up their seats to assume offices they have themselves created, or whose perquisites they have enhanced, is the subject of the Emoluments Clause. See infra notes 70-75 and accompanying text.

26. See ELSTER, supra note 19 , at 140-41.

27. We might also speak of recusal as a remedy for conflict of interest. See ANDREW STARK, CONFLICT OF INTEREST IN AMERICAN PUBLIC LIFE 10 (2000). Indeed, the same is true of veil rules. Consider the blind trust remedy in nonconstitutional conflict-of-interest law, which denies the decisionmaker information about how his decisions will affect his financial interests. I assume that very little turns on whether we use the remedial label for the rules discussed in this Section.

28. See U.S. CONST. art. I, $\S 3$, cl. 6; JOSEPH STORY, COMMENTARIES ON THE CONSTITUTION OF THE UNITED STATES $\S 389$, at 276 (Carolina Acad. Press 1987) (1833). 
the presidential succession to devolve upon, at best, the nation's third choice, for little apparent gain. But when the costs of an eligibility rule are high, constitutional design may resort, not to a recusal rule, but to a veil rule. Below, I argue that the peculiar form of the Emoluments Clause is best explained on this ground.

\section{Methodology}

If veil rules, recusal rules, eligibility rules, and the separation of powers are all available strategies for reducing self-interested decisionmaking, then constitutional designers have many degrees of freedom, which means that constitutional interpreters do as well. In the present effort, I restrict myself to veil rules, except when a contrast with other types of rules is necessary to the analysis or dispels a confusion. Even on their own terms, however, veil rules in real-world constitutional design are always shot through with compromise. As I discuss in Part III, the direct costs of excluding information from the decision process are often prohibitive, so that there is no practical alternative to a self-interested but informed decisionmaker. I also emphasize the indirect effects of veil rules on decisionmakers' motivations and activity.

A claim that a particular constitutional rule is best conceived as a veil rule is an interpretive and normative claim, not a positive hypothesis. I proceed by means of softly textualist interpretation, using originalist materials as persuasive (but not authoritative) indicators of textual meaning. ${ }^{29}$ Moreover, I build accounts of particular constitutional rules in a clause-bound style from particular provisions and their associated history and precedent; I eschew holistic comparison across clauses until the localized inquiry has independently fixed their meanings. ${ }^{30}$ The aim is to supply mid-level theory, integrating the sophisticated iterations of the veil of ignorance idea in the contractarian and constitutional choice literatures with a sensible reading of the relevant constitutional texts.

\section{VEIL TACTICS}

The veil of ignorance is an institutional-design strategy that may be implemented by a variety of tactics. I examine four particular tactics that all

29. This use of originalist materials contrasts with (what I take to be) the right conception of textualism in statutory interpretation, which eschews legislative history altogether. For the argument that the two positions are consistent, see Adrian Vermeule, Legislative History and the Limits of Judicial Competence: The Untold Story of Holy Trinity Church, 50 STAN. L. REV. 1833, 1886 n.181 (1998).

30. For a critique of holistic comparison, see Adrian Vermeule \& Ernest A. Young, Hercules, Herbert and Amar: The Trouble with Intratextualism, 113 HARV. L. REV. 730 (2000). 
attempt to introduce uncertainty about the distribution of future benefits and burdens that will result from a decision. The tactics are prospectivity, by which constitutional rules require decisionmakers to create legal rules without knowing the identities of the rules' violators; generality, which causes decisionmakers to anticipate that both the interests they favor and those they disfavor may be governed by a current decision; durability, by which rules that make decisions relatively durable cause decisionmakers to anticipate that a present decision will govern cases in the remote future, cases whose effect on the decisionmakers' future interests is presently unpredictable; and delay - that is, delay of the effective date of a rule, which restricts the range of a decision's future application to the long term, rather than the short term, in the hope that decisionmakers' long-term interests are inherently unpredictable. I conclude with a note on randomization, an obvious tactic for creating uncertainty that the law uses infrequently and constitutional law hardly uses at all (in any overt way). The surprising absence of the most direct mechanism for producing a veil of ignorance is interesting in its own right and provides a bridge to Part III, in which I consider the surprising scarcity of veil rules and explain the distribution of veil rules in the Constitution by reference to their direct and (especially) indirect, or secondary, effects.

\section{A. Prospectivity}

The simplest tactic for introducing uncertainty is to entrench a constitutional requirement that rules be prospective —enacted in advance of the events they govern. The power of retroactive legislation, for example, enables legislators to identify the winners and losers from proposed policies-to know who will bear costs and benefits as well as what those costs and benefits will be. The opportunities for legislative self-dealing are obvious if legislators can match up identified winners and losers with past or future friends and enemies, respectively. Under a prospectivity requirement, however, legislators are hard put to match up consequences with allegiances, because prediction is intrinsically more difficult and less certain than backward-looking observation, and because targets who know of the law will be able to steer clear of its prohibitions.

A related point is that a prospectivity requirement reduces uncertainty by attaching clear legal consequences to events in advance of the events' occurrence. Despite appearances, this is wholly consistent with the claim that prospectivity requirements, like other veil tactics, aim to produce beneficial uncertainty; the two observations address different issues. Consider, for example, the many instances in which the Constitution delegates authority to Congress to "provide by law" for the contingencies of presidential and vice-presidential succession in cases of death, disability, 
and so forth. ${ }^{31}$ These are simple examples of constitutional veil rules if they are interpreted to require that Congress legislate in advance of the relevant contingencies. ${ }^{32}$ Akhil Amar praises the veil-like effects of these rules on the ground that "[u]ncertainty, especially over so vital an issue as Presidential succession, is not, on balance, a virtue," so that "our Constitution... has explicitly invited Congress to lay down clear succession rules in advance of a crisis." ${ }^{33}$ But this runs together the issue of timing with the separate issue of the clarity of legal commands. Certainty in the latter sense is a function of the specificity and comprehensiveness of legal commands, and it can be attained after the relevant events' occurrence as well as before. Once the President dies, nothing at all prevents Congress from legislating quite clearly about who his successor shall be. The real fear that provokes the demand for veil rules is that after a presidential death or disability, decisionmakers' knowledge of the identities of the possible successors will provoke socially harmful, because self-interested, congressional decisionmaking, as legislators maneuver to enthrone themselves or their partisans in the White House. That fear is dampened not only by the clarity of previously enacted succession rules but also by uncertainty at the time of enactment about whose ox a given rule will gore. It is true, however, that later interpreters who know the effects of the previously enacted rule on their current interests may take advantage of any ambiguities in the rule by means of tendentious interpretation. I discuss that problem at greater length below.

There is no general federal constitutional requirement that legislation (and a fortiori adjudication) be solely or even partially prospective. The most prominent prospectivity rules in the Constitution are the Ex Post Facto Clauses, ${ }^{34}$ which forbid federal and state legislatures from enacting retroactive punishments. ${ }^{35}$ The ex post facto prohibition is best explained as a veil of ignorance rule, albeit of limited scope. An older view held that the

31. See supra note 10.

32. See Akhil Reed Amar, Presidents, Vice Presidents, and Death: Closing the Constitution's Succession Gap, 48 ARK. L. REV. 215, 227 (1994) (justifying the congressional enactment of succession rules on veil of ignorance grounds); $c f .17$ CONG. REC. 815 (1886) (statement of Sen. Sherman) ("The proposed [Electoral Count Act] comes before us ... at the beginning of an administration, when no party advantage can be derived from our decision.").

33. Amar, supra note 32, at 221.

34. See supra note 5.

35. E.g., Weaver v. Graham, 450 U.S. 24 (1981) (invalidating a Florida statute that had retroactively reduced prisoners' "gain time" for good behavior). A minor wrinkle is that the Supreme Court has occasionally read ex post facto principles into the Due Process Clause, with the result that a few cases hold unforeseeable judicial interpretations of statutes unconstitutional. E.g., Bouie v. City of Columbia, 378 U.S. 347 (1964) (holding that the South Carolina Supreme Court violated the petitioners' due process rights by retroactively applying its new construction of a state statute). But the unforeseeability requirement is construed very grudgingly, and the official view remains that the ex post facto prohibition binds only legislatures, not courts. See Rogers v. Tennessee, 121 S. Ct. 1693 (2001); Harold J. Krent, Should Bouie Be Buoyed?: Judicial Retroactive Lawmaking and the Ex Post Facto Clause, 3 ROGER WiLliams U. L. REV. 35 (1997). 
prohibition prevents unfair surprise to law-abiding citizens, but that is both circular (presumably, without the prohibition, fewer people would be surprised by retroactive criminal legislation) and morally unattractive (when, for example, the new rule punishes a defendant who previously tortured and murdered his own children, ${ }^{36}$ an act he ought to have known would upset the public's representatives).

It is a problem for the veil account that the ex post facto prohibition applies only to retroactive criminal laws and not retroactive civil laws. If identifiability is the key, why should not all retroactivity be suspect? One way out is to supplement the veil story with an interest-group tale of differential access to the political process, as does Harold Krent. ${ }^{37}$ Felons cannot vote, have no trade association and often no money, and the stigma of their past convictions or threatened retroactive convictions scares off potential political allies, so their interests will be underweighed in the legislative process. But the parties typically burdened by retroactive civil legislation have both cash and friends; they need no special judicial protection.

This is a clever story, but in the end not a convincing one. For one thing, adding interest-group analysis might cut the wrong way, suggesting that no constitutional barrier to retroactive legislation is necessary. If the retroactivity of a pending bill makes winners and losers identifiable, interest groups may lobby all the more fiercely to block the bill than they would to block prospective laws that are less clearly harmful to their interests. ${ }^{38}$ For another, the interest-group tale explains a problem at the margins of the prohibition rather than the problem at its core. Krent focuses principally upon the case in which legislation increases the punishment for previously convicted criminals. ${ }^{39}$ Sentenced offenders, as Krent argues, are hardly a politically appealing constituency. But the core concern of the prohibition is with wholly new retroactive crimes, and it is not clear that Krent's analysis works in that case. New criminals, unlike previously sentenced criminals, have the formal right to vote and the informal access to political resources that sentenced felons lack. In this respect, the veil account fits the scope of the ex post facto prohibition better than does Krent's account. If the prohibition is a veil rule, then it sensibly covers both new crimes and sentence enhancements. In either case, the key concern is legislators' ability

36. See Dobbert v. Florida, 432 U.S. 282 (1977) (upholding, against an ex post facto challenge, a retroactive change in death penalty sentencing procedure).

37. Harold J. Krent, The Puzzling Boundary Berween Criminal and Civil Retroactive Lawmaking, 84 GEO. L.J. 2143 (1996).

38. Saul Levmore, The Case for Retroactive Taxation, 22 J. LEGAL STUD. 265, 280 (1993) (arguing, in light of interest-group theory, that rules burdening identifiable groups are less likely to be enacted than rules burdening unidentifiable groups).

39. Krent, supra note 37 , at 2168 n.132. 
to identify and to specify the targets of the new criminal rule, rather than the content of the rule itself.

Rather than invoke the uncertain aid of interest-group analysis, we should probably just say that the distinction between permissible civil retroactivity and impermissible criminal retroactivity is a pseudo-puzzle. As an original matter, the ex post facto prohibition may well have been understood to cover both categories. ${ }^{40}$ As a matter of doctrine, to say that civil retroactivity is permissible is an accurate description of the ex post facto prohibition standing alone, but it is an overstatement if applied to constitutional law generally. Other clauses sometimes bar civil retroactivity that impinges on particular constitutional interests such as property; the Supreme Court has recently invalidated retroactive civil legislation under the Takings and Due Process Clauses. ${ }^{41}$ If there remains a slight mismatch between the veil account and the scope of constitutional antiretroactivity rules generally, we might understand it simply as the law's rough attempt to adjust the direct costs and benefits of veil rules. As a rough empirical generalization, subject to pervasive exceptions and boundary problems, laws imposing criminal burdens are blunter instruments, which impose cruder, more fearsome, and more stigmatizing harms on those subjected to them than do civil or regulatory laws. Conversely, the loss in impartiality that arises when relatively less-harmful civil statutes are left outside the veiled domain is more than compensated by the corresponding gains in legislative information and flexibility. ${ }^{42}$

\section{B. Generality}

Closely entangled with the idea of prospectivity is the idea of generality. A variety of constitutional rules require generality, or more accurately, push official decisions in the direction of generality across a continuum between the highly specific and the highly general. The Bill of Attainder Clauses, applicable to both federal and state governments, prevent legislatures from inflicting criminal punishments on specific, identified individuals or groups (without a judicial hearing); "special legislation" clauses in state constitutions prohibit or hamper statutes that

40. The Clause was held to cover only criminal legislation in Calder v. Bull, 3 U.S. (3 Dall.) 386,390 (1798). But that holding was hotly contested at the time. Satteriec v. Matthewson, 27 U.S. (2 Pet.) 380, 414-16 (1829) (Johnson, J., dissenting). It is still controversial in originalist circles today. See, e.g., E. Enters. v. Apfel, 524 U.S. 498, 538 (1998) (Thomas, J., concurring) (expressing his willingness to overrule Calder).

41. E. Enters., 524 U.S. at 537 (plurality opinion) (invalidating a retroactive civil statute as an uncompensated taking of property); $i d$. at 539 (Kennedy, J., concurring in part and dissenting in part) (reaching the same result under a due process analysis).

42. Perhaps the Justices in Calder v. Bull intuited this point. See 3 U.S. (3 Dall.) at 400 (Iredell, J.) (warning that " [w] ithout the possession of this power [to enact retroactive civil laws] the operations of government would often be obstructed"). 
impose special burdens, or (in some states) statutes that confer special benefits, on particular individuals, groups, or geographic areas; ${ }^{43}$ various constitutional requirements of uniformity prevent disparate treatment of different states or regions; ${ }^{44}$ and the equal protection requirement serves as a constitutional backstop that may be invoked to scrutinize both federal and state official action that seems excessively targeted against identified individuals or classes.

The generality requirement, like the prospectivity requirement, is said to produce veil effects that deprive decisionmakers of the information needed to pursue selfish or partial interests. " $[\mathrm{G}]$ eneralizations place people behind the veil of ignorance, depriving them of the knowledge of whether [a rule's] application will help or hurt themselves or their friends." ${ }^{45}$ If legislators, for example, must frame statutes in general terms, rather than tailoring their proscriptions to identified or (at least) identifiable enemies, there will be some risk, however small it may be in practice, that the legislator himself (or his allies) will fall subject to the law. That risk will moderate the legislator's hostility or indifference to disfavored individuals or groups, bringing decisions more nearly into line with impartial decisionmaking, however defined.

Untangling the relationship between generality and prospectivity helps us to appreciate the work that each requirement does. Granting that "the legislature must prescribe penalties generally and prospectively, behind a suitably impersonal veil of ignorance," ${ }^{46}$ we may wonder whether either generality or prospectivity does any veil-generating work on its own, absent the other. Consider the following three hypothetical cases: ${ }^{47}$

(1) A statute providing that "all those who hereafter steal from another shall be put to death."

(2) A statute providing that "all those who have previously stolen from another shall be put to death" (where either there was no

43. Robert F. Williams, Equality Guarantees in State Constitutional Law, 63 TEX. L. REv. $1195,1196(1985)$.

44. U.S. CONST. art. I, \& 8, cl. 1 (" [A]Il Duties, Imposts and Excises shall be uniform throughout the United States...."); $i d$. art. I, \& 8, cl. 4 ("Congress shall have power... To establish an uniform Rule of Naturalization, and uniform laws on the subject of Bankruptcies throughout the United States ...."); id. art. I, $\S 9$, cl. 6 ("No Preference shall be given by any Regulation of Commerce or Revenue to the Ports of one State over those of another ....").

45. Richard A. Epstein, A Common Law for Labor Relations: A Critique of the New Deal Labor Legislation, 92 YALE LJ. 1357, 1364 (1983); see also RICHARD A. EPSTEIN, TAKINGS 240 (1985) (justifying general tort rules on veil of ignorance grounds). For a recent attempt to make generality the master principle of constitutional choice, see JAMES M. BUCHANAN \& ROGER D. CONGLETON, POLITICS BY PRINCIPLE, NOT INTEREST (1998).

46. Akhil Reed Amar, Attainder and Amendment 2: Romer's Rightness, 95 MicH. L. REV. 203, 210 (1996).

47. These hypotheticals are inspired by, but are different from, a series of cases examined id. at 211-13. 
preexisting theft statute or the preexisting statute imposed a lesser penalty).

(3) A statute providing that "anyone named Vermeule who hereafter steals from another shall be put to death" (where there is no other, general theft statute in force, and only one person named Vermeule).

The first statute is both general and prospective, the second general but retroactive, and the third prospective but extremely specific. Under current doctrine the first is clearly valid, while the second clearly violates the Ex Post Facto Clause. It might be said that the generality of the second statute imposes a sufficient veil of ignorance, because the legislators will be unable to identify the distribution of the law's burdens with any precision, but that is only true in a very partial sense. Legislators enacting a general but retroactive statute may not know precisely who falls within the statute's terms, but because the statute is retroactive they need only know whether they and their allies have already committed the relevant crime in the past; if they have not, then the statute's burdens can only ever fall upon outsiders.

The third statute presents a somewhat more difficult case than the first two. In a challenge to the statute brought under the Bill of Attainder Clause, the key question would be whether the statute is excessively specific, but the notion of "specificity" may itself be cashed out in different ways. One view has it that legislation displays unconstitutional specificity when, and perhaps only when, "the legislation defines a closed class, a class with a membership that is permanently fixed when the class is defined, from which members can never exit and into which nonmembers can never enter." ${ }^{48}$ Yet, as the Supreme Court has noted, the closed-class test proves too restrictive if it supplies a sufficient condition for an attainder violation, because it would prohibit the imposition of seemingly benign burdens. Consider a statute that forbids epileptics from operating dangerous machinery without a license, on pain of criminal sanctions. ${ }^{49}$ So another view has it that the touchstone must be whether the legislative purpose in defining a suspiciously small or impermeable class is punitive or legitimately nonpunitive. On the latter view, the epileptic-licensing statute pursues a nonpunitive or essentially regulatory end and is therefore acceptable, while a statute making it a crime for any present or past member

48. Roderick M. Hills, Jr., Is Amendment 2 Really a Bill of Attainder? Some Questions About Professor Amar's Analysis of Romer, 95 MICH. L. REV. 236, 240 (1996).

49. See United States v. Brown, 381 U.S. 437,454 n.29 (1965); LAURENCE H. TrIBE, AMERICAN CONSTITUTIONAL LAW 646 n.25 (2d ed. 1988). 
of the Communist Party to serve as a labor-union officer embodies punitive purposes and thus constitutes a forbidden attainder. ${ }^{50}$

Probably either view would condemn the third statute. Under the closed-class view, a statute subjecting a named individual (or an equivalent class of one) to a legal disability is a paradigmatic attainder. ${ }^{51}$ Even under the more permissive nonpunitive-purpose view, it is hard to imagine a nonpunitive rationale for legislating against a named individual that would not apply to some other potential malefactor as well. One could label the latter point as an equal protection problem rather than an attainder problem, but the core concern about inadequate generality is the same under either rubric. Hence, prospectivity without generality is as condemnable as generality without prospectivity, and the upshot of the hypotheticals is that the twin requirements of prospectivity and generality both do some independent, veil-generating work. The former prevents decisionmakers from reaching into the past to burden identified parties, while the latter prevents decisionmakers from loading down identified parties with special future burdens.

This account may load the dice by using examples that impose burdens rather than benefits. Constitutional rules that restrain the retroactive imposition of burdens, such as the ex post facto prohibition, usually do not restrain retroactive benefits at all. Likewise, the Bill of Attainder Clauses do not prevent legislatures from singling out named beneficiaries for special largess. It might be thought embarrassing for the veil of ignorance account of prospectivity and generality that these rules reach only burdens. If the core feature of a veil rule is that it denies decisionmakers the ability to act on information about identified or identifiable individuals or groups in order to promote impartial decisions, the restriction of the ex post facto and attainder prohibitions to burdens rather than benefits may suggest that the current constitutional rules are underinclusive.

This objection, while not frivolous, is probably overblown. First, a doctrinal point in the federal system is that while general benefits are usually immune from constitutional challenge, specific benefits are always subject to an equal protection challenge for lack of a rational basis, and will be strictly scrutinized if the specific class of beneficiaries is defined along illicit lines. ${ }^{52}$ In state systems, "special legislation" clauses go even farther toward prohibiting targeted benefits. In terms of constitutional clauses, the generality and prospectivity requirements are better tailored to the veil

50. See Brown, 381 U.S. at $450-56$.

51. Notwithstanding the dubious decision in Nixon v. Administrator of General Services, 433 U.S. 425,472 (1977), which held that a statute specifically regulating the disposition of former President Nixon's papers, and of his alone, did not amount to a bill of attainder because Nixon constituted a "legitimate class of one."

52. See, e.g., Heckler v. Mathews, 465 U.S. 728 (1984) (upholding a gender-discriminatory allocation of social security benefits). 
rationale than a constricted focus on the ex post facto and attainder prohibitions might indicate. Second, the harms of self-interested legislative decisionmaking are plausibly higher where decisions selectively allocate burdens than where decisions selectively allocate benefits, despite the abstract economic equivalence between losses and foregone gains. Constitutional designers might intuitively grasp that, for good or bad cognitive reasons, the law's subjects count the selective imposition of a burden, measured from some preexisting baseline, as a more grievous loss than the selective denial of an opportunity to receive some benefit, measured from the same baseline. ${ }^{53}$

\section{Durability}

A standard claim in the constitutional choice literature holds that as the durability of rules is increased toward the limit case of permanence, constitutional designers become increasingly uncertain about how the choice of rules will affect their future interests. ${ }^{54}$ Durability means that the designer must take into account long-term as well as short-term effects; the inherent unpredictability of long-term interests means that the designer can do no better than to choose impartially. ${ }^{55}$ The veil of ignorance arguments advanced at the Federal Constitutional Convention, noted by several commentators, have precisely this structure. In arguing for direct popular election of House members, rather than election by state legislatures, George Mason argued that:

We ought to attend to the rights of every class of the people. He [Mason] had often wondered at the indifference of the superior classes of society to this dictate of humanity \& policy, considering that however affluent their circumstances, or elevated their situations, might be, the course of a few years, not only might but certainly would, distribute their posterity throughout the lowest classes of Society. Every selfish motive therefore, every family attachment, ought to recommend such a system of policy as would

53. See Herbert Hovenkamp, Legal Policy and the Endowment Effect, 20 J. LeGal STuD. 225 (1991).

54. See, e.g., BRENNAN \& BUCHANAN, supra note 4, at 29-30.

55. An important special case of durability arises where the decisionmaker anticipates that she will occupy different, even opposed, roles in a series of future transactions that will be governed by a durable legal rule. This veil mechanism appears most commonly in nonconstitutional contexts. A decisionmaker who must choose rules of contract law, for example, might be led to choose impartially by anticipating that (1) the rules will govem a long series of future contracts and that (2) she will sometimes occupy the role of buyer, sometimes the role of seller. 
provide no less carefully for the rights-and happiness of the lowest than of the highest orders of Citizens. ${ }^{56}$

Likewise, Gouverneur Morris decried the delegates' attachments to the interests of their home states, on the ground that "after all how little can be the motive yielded by selfishness for such a policy. Who can say whether he himself, much less whether his children, will the next year be an inhabitant of this or that State." 57 Similar examples are strewn throughout the Convention records.

The sub-literatures on particular constitutional rules transpose the durability claim from the level of decisions about constitutional rules to the in-system level of decisions made under constitutional rules. Here, the idea is that rules increasing the durability of in-system decisions will produce veil-like effects, as long as decisionmakers are aware that their decisions will remain in place for long periods. Thus Article V's relatively onerous procedures for constitutional amendment have been said to produce a veil effect because amenders have to abide by the amendment in remote future circumstances that they are unable to predict at the time of amendment. ${ }^{58}$ Procedures for constitutional amendment are a special case, because they govern decisions of a hybrid character; proposals for amendment are offered by within-system decisionmakers, but once effective the decision has constitutional status, and to that extent represents an exercise of constitutional choice within a restricted domain. A cleaner example is the set of rules that govern the durability of constitutional interpretations rendered by in-system decisionmakers, principally the doctrine of stare decisis for constitutional questions. Here the claim is that interpreters will reason impartially if they anticipate that the decision may be invoked in future cases whose valence in terms of the decisionmakers' future interests is unpredictable. Upholding the free speech claim of a left-wing dissenter now may require upholding the free speech claim of a right-wing dissenter later. $^{59}$ The point generalizes beyond judicial decisionmaking to any institution that follows a de jure or de facto norm of precedent. If Republican senators impeaching a Democratic president in 1998 know that their interpretations of the relevant constitutional provisions may govern the impeachment of a Republican president by Democratic senators on some

56. 1 THE RECORDS OF THE FEDERAL CONVENTION OF 1787, at 49 (Max Farrand ed., 1966).

57. Id. at 531 .

58. See Fitts, supra note 11, at 967 n.173; John O. McGinnis, The Inevitable Infidelities of Constitutional Translation: The Case of the New Deal, 41 WM. \& MARY L. REV. 177, 209 (1999).

59. See Collin v. Smith, 578 F.2d 1197 (7th Cir. 1978) (invalidating a village ordinance that barred peaceful demonstrations by the American Nazi Party). 
unpredictable future occasion, the claim runs, they will be pushed toward impartial interpretations, or at least moderate ones. ${ }^{60}$

Durability is analytically distinct from generality. A fact-specific decision may be quite durable in the empty sense that it governs no future cases and thus provides no occasion for reconsidering its force, while general rules often prove short-lived. But there is a plausible empirical connection between the two features. Constitutional designers might require in-system decisions to be durable as well as general in order to prevent decisionmakers from circumventing generality requirements. If generality requirements are only imperfectly enforceable, a decision cast in adequately general terms that favors decisionmakers' short-term interests will prove more attractive if the decision can be rescinded once it has done its work, less so if it will remain in force for the remote future. As I discuss shortly, however, the converse point is that durability without generality will not succeed in producing a veil effect. A durability requirement can be circumvented if the original decisionmakers can issue a decision of excessive specificity, or if subsequent decisionmakers can eviscerate a prior decision by narrow interpretation.

Despite the frequent invocation of durability as a veil-producing mechanism, it is hardly clear that durability successfully dampens decisionmakers' self-interest. First, the mechanism supposes, implausibly, that decisionmakers' time preferences are constant across all future periods. If decisionmakers substantially discount the future, however, it is perfectly rational for them to choose rules according to their short-term interests. If the rule indicated by short-term expediency is sufficiently beneficial, the discount rate will ensure that its expected value overwhelms other candidates even if that rule has predictably adverse effects on long-term interests. Introducing uncertainty about long-term interests does nothing to dilute the effect of the discount rate; indeed it strengthens it. Furthermore, when the decisionmaker has decent information about the short-term effects of the rule, as is often the case, ordinary principles of decisionmaking under uncertainty will counsel that the unpredictable long-term effects of the rule should be ignored; the decisionmaker should take the bird in hand without worrying about what is left in the bush. ${ }^{61}$ The veil arguments advanced at the Federal Constitutional Convention proved largely inadequate to overcome this effect. In many cases, although not all, delegates from small and large states pursued their own and their principals' short-term interests,

60. See Neal Kumar Katyal, Impeachment as Congressional Constitutional Interpretation, 63 LAW \& CONTEMP. PROBS. 169, 186 (2000).

61. See Robert E. Goodin, POlitical Theory and Public Policy 162-83 (1982) (comparing an approach that discounts the distant future with an approach that ignores it on decision-theoretic grounds); Adrian Vermeule, Interpretive Choice, 75 N.Y.U. L. REV. 74, 123-28 (2000) (explaining why decisionmakers might rationally ignore the speculative future consequences of their decisions). 
making it necessary to settle the major choices not only by rational argument but also by frank bargaining. ${ }^{62}$

A second problem is that rules that make decisions relatively durable may be quite difficult to enforce, both in an ex ante sense and an ex post sense. The ex ante sense is that decisionmakers who anticipate the durability of rules may opt for fact-specific standards, precisely in order to circumvent the veil effect of durability. A highly specific decision guts durability of any substance; the initial decision will govern any future cases to which it applies, but it won't apply to any future cases. An example is Bush v. Gore, in which the Court built into its equal protection holding a statement that its analysis was limited to the precise facts before it. ${ }^{63}$ By making the decision a ticket good for one day only, the Court sidestepped the veil effect that would have obtained had the Court been subjected to ex ante uncertainty about whether its holding might have rebounded in harmful directions in future cases. (Even that uncertainty might have proved a feeble constraint, of course, given that the majority might well have preferred to take the gains from deciding a current presidential election even at the price of losses in future cases contesting elections to lesser offices-the point about discount rates again.)

Durability rules are also extremely porous in an ex post sense. Subsequent decisionmakers will attempt to undo prior decisions that constrain their current interests, and for two reasons they will often succeed. First, no durability rule does or could make an initial decision permanent-under current law, there is no absolute rule of stare decisis, even for cases of statutory interpretation. The normative case for rejecting absolute stare decisis is that later decisionmakers have better information than initial decisionmakers about the current effects of prior decisions in light of changing social circumstances. Here again, hoped-for veil effects are compromised by the need to ensure that decisionmakers possess adequate information. But the revisability of decisions also means that subsequent decisionmakers may opportunistically overturn prior decisions that disfavor them (at present), and if their information is also better than that of contemporaneous observers, it will be difficult for those observers to sort out warranted from unwarranted revisions. Second, even short of an outright overruling or revision of an earlier decision, the earlier decision is only as robust as whatever theory of interpretation is subsequently in place.

62. Jon Elster, Arguing and Bargaining in Two Constituent Assemblies, 2 U. PA. J. CONST. L. 345 (2000); Robert A. McGuire, Constitution Making: A Rational Choice Model of the Federal Convention of 1787, 32 AM. J. POL. SCI. 483 (1988) (stating that voting patterns at the Federal Convention correlated with the economic interests of constituents and, less strongly, with the economic interests of the delegates themselves).

63. See Bush v. Gore, 531 U.S. 98, 109 (2000) (per curiam) ("Our consideration is limited to the present circumstances, for the problem of equal protection in election processes generally presents many complexities."). 
If the interpretive rules are loose, clever readings can narrow or distinguish inconvenient decisions ex post almost to the same extent that decisions can be limited ex ante.

As a conceptual matter, this sort of subsequent gamesmanship does not detract from the ex ante veil effect produced by a durability requirement, but the twist is that the ex post unenforceability of durability rules can be anticipated by the initial decisionmakers themselves. Those decisionmakers may reason that moderating their current decisions in order to forestall the possibility that the decision will rebound harmfully in future cases is foolish. If future interpreters of the current decision are hostile to the future interests of the current decisionmakers, and if the boundaries of fair interpretation are very loose, then the future interpreters will not be constrained to abide by the moderate character of the initial decision in any event. This dynamic undercuts Neal Katyal's claim that if there is a norm of legislative stare decisis, Republicans interpreting the constitutional standards for impeachment in the case of a Democratic president will moderate their decisions to forestall a future impeachment in the opposite direction. ${ }^{64}$ Current Republicans may reason that future Democrats can and will distinguish or redescribe the current decision in any event, so that current restraint would amount to nothing more than unilateral disarmament.

\section{Delayed Effectiveness}

The pervasive weakness of the durability mechanism is that decisionmakers remain aware of their short-term interests, and if they discount sharply enough, or have decent information only about the short term, they will rationally ignore the long-term uncertainty produced by the durability requirement. A strategy that attempts to lengthen the time horizon is to delay the effectiveness of decisions, either for some fixed period or until after some future event. An example might be a constitutional rule providing that all ordinary legislation will take effect only $X$ years after the date of enactment. ${ }^{65}$

A delayed-effect rule produces a veil effect only in an indirect sense. Such rules impose no direct restriction on decisionmakers' information, nor do they introduce a new source of uncertainty. Instead, delay rules take advantage of a preexisting uncertainty - the inherent unpredictability of the

64. See Katyal, supra note 60, at 186.

65. "Ordinary" legislation should be understood to mean legislation that is, among other things, solely prospective when it does enter into cffect. This excludes the intricate, but unprofitable, analytic complexities that would arise if legislatures could enact laws that would, upon taking effect after a delay, have retroactive effects on conduct occurring before or during the period of delay. 
decisionmakers' long-term interests-that would otherwise be overwhelmed by the incentives to focus on short-term considerations. By confining the range of the decision's application to cover only the period (beyond the delay period) in which decisionmakers' interests are unpredictable, a delay rule ensures that the only period current decisionmakers can affect is one that is, from their ex ante standpoint, subject to a veil of uncertainty.

The example of a general constitutional rule that explicitly delays the effective date of ordinary legislation is obviously fanciful, and that is interesting in itself. I subsequently address why we do not see constitutional provisions of that sort. ${ }^{66}$ Nonetheless, there are constitutional rules that might be explained or rationalized as incorporating a delay strategy of a sort. I will discuss two examples: the Twenty-Seventh Amendment and the Emoluments Clause.

The Twenty-Seventh Amendment provides that "[n]o law varying the compensation for the services of the Senators and Representatives shall take effect until an election of Representatives shall have intervened." ${ }^{67}$ The Amendment was not formally ratified until 1992, but that is irrelevant for my current purpose, which is to use the Amendment as an example of the delaying tactic, rather than to make claims about its historical significance. The purpose and effect of the provision is less obvious at the second glance than at the first. Certainly the target is legislative self-dealing over salary and other compensation, a serious concern given the Constitution's vesting of appropriations power in the legislature. But the question is why the ordinary operation of the election cycle will not prevent legislators from conspicuous feeding at the public trough. On standard public-choice premises, constitutional designers should worry more about less visible forms of self-dealing, such as kickback schemes and in-kind exactions from citizens affected by legislation. Put differently, the Amendment cannot be explained as an attempt to restrain legislators by subjecting them to the anticipation of a post-hoc electoral check. That motive would operate with full force even in the absence of the Amendment as long as the pay raise

66. The closest analogue in the Federal Constitution is a matched pair of rules in Article I and in Article V. The Article I provision forbade Congress from prohibiting the "Migration or Importation of such Persons as any of the States now existing shall think proper to admit" (read: slaves) until the year 1808 . U.S. CONST. art. I, $\S 9, \mathrm{cl}$. 1. The latter provision made the former provision unamendable before 1808 (at which point any amendment would be moot). Id. art. V. But the analogy is not very close. These rules prohibited action until a particular time certain; Congress could and did legislate in 1807 with no uncertainty at all about the distribution of benefits and burdens from the decision. DAVID P. CURRIE, THE CONSTITUTION IN CONGRESS: THE JEFFERSONIANS, 1801-29, at 6-7 (2001) (describing federal legislation enacted in 1807 that abolished the slave trade). A delayed-effectiveness rule, by contrast, produces veil-like effects only because it builds in a delay period that attaches no matter when the legislation is enacted or the decision made.

67. U.S. CONST, amend. XXVII. 
became public knowledge, and publicity is guaranteed elsewhere by constitutional rules that require each house of Congress to publish the journal of its proceedings, that require appropriations to be made by (published) statutes, and that require regular publication of the expenditures of all public money.

The key to the Amendment's design is that it delays the effective date of a legislative pay raise until after the next election (of representatives). The delay prevents legislators from benefiting during the interim period, and thus ensures that legislators will not consider the question of appropriate pay under the distorting influence of short-term personal interest. As Madison said while introducing the Amendment in the First Congress:

Perhaps of all the powers granted, it [i.e. the legislative power to set legislators' salaries] is least likely to abuse; but there is a seeming impropriety in leaving any set of men without control to put their hand into the public coffers, to take out money to put in their pockets; there is a seeming indecorum in such power.... I have gone, therefore, so far as to fix it, that no law, varying the compensation, shall operate until there is a change in the Legislature ${ }^{68}$ in which case it cannot be for the particular benefit of those who are concerned in determining the value of the service. ${ }^{69}$

Madison's explanation was not perfectly tailored to the scope of the rule proposed. To ensure that a salary increase could not operate for the "particular benefit" of the legislators who voted on it would instead require an eligibility restriction, either one that made legislators ineligible for election to a new Congress after voting for a (delayed) salary increase, or one that denied legislators a component of salary equivalent to the increase for which the legislator previously voted. But the Twenty-Seventh Amendment achieves a similar effect by introducing uncertainty about personal benefit, through the strategy of delay. Marginal legislators who are unsure whether they will maintain their seats after the next election will also be unsure whether a current vote for a delayed salary increase will benefit themselves or instead benefit future legislators who will have replaced them, perhaps political rivals from their home states or districts. Without the delay provision, legislators who anticipate a risk of losing the

68. This was an inaccuracy on Madison's part. The Amendment, as drafted and as eventually enacted, requires a delay only until the next election of representatives, not (also) of senators. We should probably see this as a raw compromise with the costs of delay: Waiting until after the whole Senate had been subject to reelection-that is, until after the next three senatorial elections-would prevent a medium-term adjustment of legislative salaries for little marginal gain in impartial decisionmaking.

69. I ANNALS OF CONG. 457-58 (Joseph Gales ed., 1789) (emphasis added). 
next election would be especially likely to vote for the short-term benefit of an immediate pay raise; with the delay provision, they are especially unlikely to do so.

A more complicated and historically more important example is the Emoluments Clause, which provides that " $[\mathrm{n}] \mathrm{o}$ Senator or Representative shall, during the Time for which he was elected, be appointed to any civil Office under the Authority of the United States, which shall have been created, or the Emoluments whereof shall have been encreased during such time." ${ }^{70}$ Justice Story's view was that the Clause attempts to suppress "venality." As Story wrote, "[t]he reasons for excluding persons from offices, who have been concerned in creating them, or increasing their emoluments, are, to take away, as far as possible, any improper bias in the vote of the representative, and to secure to the constituents some solemn pledge of his disinterestedness." ${ }^{11}$ Absent the Clause, not only would legislators have the power to vote on the existence or perquisites of offices they would be eligible to fill, but they could strike collusive deals with the President, distorting policy in other areas in order to obtain a presidential promise of future appointment to a new or enhanced office.

Here too, however, the precise scope of the Clause seems poorly tailored to the aim of suppressing venality. Subjecting each legislator to a permanent ineligibility to federal offices that were created or whose emoluments were increased during the legislator's term would detach selfinterest from decisions about the existence and compensation of federal offices. ${ }^{72}$ Instead, the Clause as enacted only makes the legislator ineligible for appointment during the term for which the legislator was elected. The historical explanation for this slight mistailoring is that the current form of the Clause was a compromise among the Convention delegates. An initial proposal would have made legislators ineligible for any federal office for up to one year after the legislator's term ended. Madison's eventual proposal, which he described as a "middle ground," 73 restricted the Clause along both dimensions to palliate other delegates' concerns that a broad

70. U.S. ConST. art. I, $\S 6$, cl. 2.

71. STORY, supra note $28, \S 440$, at 311 . A somewhat different account of the purpose of the Clause emphasizes the fear that legislative-executive collusion would create an excessive number of new federal offices, expanding the federal government at the expense of the states. John $\mathbf{F}$. O'Connor, The Emoluments Clause: An Anti-Federalist Intruder in a Federalist Constitution, 24 HOFSTRA L. REV. 89, 164-68 (1995).

72. This is something of an exaggeration, because even a permanent disability would leave scope for legislators to advance friends and relatives to federal offices, to create a new office in the hope of assuming an old office after its current occupant has moved to the new one, or to carry out other subtle schemes of cvasion. But the Framers argued that suppressing the core case of biased decisionmaking would be worthwhile even if other (but costlier) substitutes remained available. 1 THE RECORDS OF THE FEDERAL CONVENTION OF 1787, supra note 56, at 387-89.

73. Id. at 308 . 
ineligibility would discourage too many talented but ambitious candidates from seeking federal legislative office.

Purely as a textual matter, however, the actual wording of the Clause might be justified as a delay rule aiming to produce uncertainty and consequent veil-like effects. Consider the choices facing a legislator who must vote up or down on a bill to create a new office or increase the emoluments of an old one, and who has some hope or expectation of obtaining executive nomination and confirmation to the office. Absent the Clause, the legislator may strike a deal to obtain executive appointment as the price of supporting the bill, vote for the bill, and assume the office, all during the current electoral term (although a different constitutional rule that prohibits simultaneous service in the legislative and executive branches requires him to surrender his current legislative office as the price of moving into the executive). With the Clause, the legislator knows that if the bill is enacted, he will be ineligible to be nominated ${ }^{74}$ to the new or enhanced office until after the end of his current term. ${ }^{75}$ That delay increases the legislator's uncertainty about whether he will benefit from the creation or enhancement of the office. For one thing, the postponement decreases the credibility of a presidential promise, given at the time of the vote, to nominate the legislator in the future. The legislator will anticipate that if he loses the intervening election, the President may decide that he can renege without incurring the wrath of any current legislator (one of whom may be offered the job in place of the former legislator), and will also anticipate that if the intervening election coincides with a presidential election, the President may not be around to fulfill the promise anyway. For another thing, the delay takes advantage of the inherent unpredictability of future politics. The legislator may, for example, anticipate or fear that the intervening election will change the composition of the Senate in such a way as to preclude a realistic chance of obtaining senatorial confirmation to a principal office.

Legislative salaries and appointment to federal office were two areas of paramount concern to Framers who feared self-interested legislative

74. Not merely confirmed to the office. The consistent practice has been to treat nomination as a component of appointment. O'Connor, supra note 71 , at 105 . The legislator may not, therefore, demand that the President nominate him to the office before voting on the bill-any action necessary to place the legislator in the new or enhanced office must wait until after the completion of the legislator's term.

75. In this century, the Clause has been partially diluted by the so-called Saxbe fix, in which Congress attempts to remove a legislator's disability under the Clause by reducing the compensation of the office to the level prevailing at the beginning of the legislator's current electoral term. Therefore, if Congress raises the salary of the Secretary of the Treasury, and the President nominates a sitting senator to the post, the Saxbe fix purports to remove the senator's ineligibility. See Michael Stokes Paulsen, Is Lloyd Bentsen Unconstitutional?, 46 STAN. L. REV. 907, 908-09 (1994). Nothing I say here turns upon the much-debated question whether the Saxbe fix is constitutional. 
decisionmaking. The corresponding provisions, the Twenty-Seventh Amendment and the Emoluments Clause, are structured around delay mechanisms that introduce uncertainty about the distribution of benefits from the relevant decisions. The veil of ignorance strategy, then, is an important feature not only of negative restrictions on legislative action, such as the Ex Post Facto and Bill of Attainder Clauses, but also of structural constitutional law. Veil rules are a central feature but not a pervasive one; there remains a set of puzzles about why the veil rules we have are the only ones we have, and why the ones we have are located where they are. I take up these questions in the next Part, after a digression on randomization.

\section{E. A Note on Randomization}

A straightforward means for producing a veil effect is to institute random selection over some future state of interest to decisionmakers. Randomization might render unpredictable the distribution of future benefits and burdens from a current decision or cut the causal tie between a present decision and future advantage. At the limit, for example, we might imagine rules that randomly selected the effective date of legislation, thereby diluting representatives' incentives to pursue short-term plans; or that randomly allocated legislators to districts for electoral purposes, thereby diluting legislators' incentives to pander to constituent preferences. Randomization proposals have been advanced for other institutions as well. Consider John McGinnis's proposal for random selection of lower court judges to serve on Supreme Court panels, which McGinnis justifies in part by arguing that a veil of ignorance effect would arise when judges must vote on certiorari petitions without knowing the identity of the judges who will ultimately hear and decide the case. ${ }^{76}$

The fanciful character of these examples poses a puzzle. Why is it that neither constitutional text nor constitutional doctrine contains explicit, overt randomization mechanisms? We may say, tongue partly in cheek, that some particular body of Supreme Court doctrine is so full of near-arbitrary distinctions as to seem almost random, but then the word is just a synonym for chaotic. And nonconstitutional rules, by comparison, do embody overt random-selection mechanisms. Some of the many examples are the

76. John O. McGinnis, Justice Without Justices, 16 CONST. COMMENT. 541, 545 (1999). In a similar vein is Michael Abramowicz's ingenious proposal that an banc decision in any one federal circuit court of appeals should be made by courts of appeals judges randomly selected from other circuits-a proposal that Abramowicz justifies, in part, on the veil-like ground that "judges might make better decisions when the identities of those who will review the decisions are unknown." Michael Abramowicz, En Banc Revisited, 100 CoLUM. L. REV. 1600, 1603 (2000). 
selection of jury pools, selection of judicial panels within a larger circuit court, and lotteries awarding scarce administrative resources such as radio spectrum. Most of these are not defended precisely on the basis that they produce veil effects, but most can plausibly be understood as devices for minimizing self-interested or strategic behavior by litigants or officials, including corruption or outright bribery, so the analogy is close.

In constitutional law, however, any randomization mechanisms must be wrung out of the existing rules through aggressive interpretation or attribution. Consider Joseph Bessette's idea that the original constitutional device for selecting federal senators-election by state legislators-might be seen as taking advantage of Hamilton's concern that state legislatures were riven by political turmoil, producing "inconstancy" and "mutability." "7 By virtue of that very fact, senators elected by state legislatures would be unable to predict the eventual political effect of votes cast in the first several years of their term. Denied the information needed to maximize their chances of reelection, senators would be forced to vote according to some broader conception of the public interest. ${ }^{78}$ The claim is an ingenious attribution of veil effects, but as either a positive account of the genesis of the selection scheme or a normative defense of it, Bessette's idea seems ancillary to the major consideration, which was that representatives chosen by state legislators would represent states in one branch of the new federal legislature.

Perhaps eighteenth-century constitutional designers failed to appreciate that randomization could dampen strategic behavior and self-interested decisionmaking. But it turns out that random-selection mechanisms, particularly the random selection of legislators, have ancient roots in the constitutions of Greece, Rome, and European states of the premodern period; surely at least some of the classically educated Framers were aware of at least some of these rules. ${ }^{79} \mathrm{~A}$ more promising line of inquiry would tie the absence of constitutional randomization to the Framers' view that "reason" supplied the measure of good constitutional design. As Jon Elster argues, although the use of randomization mechanisms can be supported by good reasons, their application often savors of an irrational or arational obeisance to chance that rationalists find discomfiting. ${ }^{80}$ Lacking competence as an intellectual historian, I pursue this no further, but the notable absence from constitutional law of one straightforward device for

77. THE FEDERALIST No. 73, supra note 20, at 419 (Alexander Hamilton).

78. See JosePH M. BESSETTE, THE MILd VOICE OF REASON 25 (1994).

79. See Bernard Manin, The Principles of RePresentative Government $42-93$ (1997).

80. See JON ELSTER, SOLOMONIC JUDGMENTS 36-37 (1989) (explaining "the nonadoption of lotteries in situations where they would seem to be normatively compelling" on the basis that "we have a strong reluctance to admit uncertainty and indeterminacy in human affairs. Rather than accept the limits of reason, we prefer the rituals of reason"). 
producing veil effects emphasizes that it is as interesting to consider where and why constitutional law declines to use veil strategies as it is to consider where and why it uses them. The next Part takes up that theme.

\section{The DistRIBUTION OF VEIL RULES}

A striking feature of the veil rules explicated in Part II is their skewed distribution across the Constitution. The Ex Post Facto and Bill of Attainder Clauses constrain Congress, but there are no similar checks on independent executive action, ${ }^{81}$ and only a weak form of ex post facto check on judicial decisionmaking. ${ }^{82}$ The Twenty-Seventh Amendment and the Emoluments Clause constrain legislative self-dealing and collusion with the executive, but there are no equivalent checks on independent executive or judicial action. If this unequal distribution does not seem puzzling, it is only because it is so familiar. There is no reason rooted in the nature of things why constitutional rules might not aim to produce much more pervasive veil-like effects on executive and judicial decisionmaking.

Start with the executive branch. Is presidential decisionmaking necessarily retrospective and specific, because it is by some essential definition an exercise of the power to execute rather than to legislate? The pardon power, for example, could easily be subjected to requirements of prospectivity and generality; it would then resemble the powers of suspension and dispensation-prospective waivers of general laws-that were long claimed by the English crown. ${ }^{83}$ So, too, with the power to prosecute. Under the current constitutional rules, Congress may not enact a retroactive criminal statute that identifies and punishes individuals for

81. By "independent" executive action, I mean executive action taken pursuant to a freestanding grant of constitutional authority, such as the pardon power or the power to appoint principal officers, rather than action taken in the President's capacity as a participant in the process of statutory enactment, such as the signature or veto of a bill. So I assimilate restrictions on the President's action in his capacity as legislator-in-chief into restrictions on the Congress itself. That the President, for example, may not constitutionally sign into law a bill that raises legislative salaries until an election of representatives has intervened-because the TwentySeventh Amendment bars such a law - counts, in my view, as a restriction on Congress, not on the President. The rationale for the categorization, in this example, is not that the salaries being raised are those of the Congress. The Constitution also prohibits altering the President's salary during his term of office, U.S. CONST. art. II, $\S 1$, cl. 7 (thanks to Saul Levmore for reminding me of this provision), but since the President's salary must be altered by statute, that rule too counts in my schema as a restriction on Congress. Classifying veil rules in this way may overstate the skewed character of the constitutional distribution, but classifying such cases as restrictions on the President might be taken to understate the skew. There is no neutral baseline. 1 have chosen the former approach because the Framers invariably conceived rules such as the Ex Post Facto Clause as restrictions on legislative rather than executive power, despite the fact that such rules prevent the President from signing a retroactive criminal law just as much as they prevent the Congress from enacting one.

82. See supra note 35 .

83. See 6 W.S. Holdsworth, A History OF ENGLiSh LAw 217-25, $240-41$ (1927). 
actions undertaken in the past, but the executive may wait until identified individuals have violated the statute and then select particular violators for prosecution. A more veiled approach would require prosecutors to enact and abide by general and prospective guidelines for exercising prosecutorial discretion-akin to requiring that the Justice Department's prosecution guidelines be given legal force. ${ }^{84}$

The point holds for judicial decisionmaking as well. Judges could be subjected to veil effects by randomization, as in McGinnis's proposal, by anticipated durability, as a less malleable doctrine of precedent might accomplish, or by pushing courts to decide cases prospectively in order to suppress bias-inducing information. Federal courts, for example, might be permitted or even required to issue advisory opinions in advance of controversies, without knowledge of the identity of particular litigants or of particular facts; courts in several states and in other countries are subject to a variety of similar requirements. ${ }^{85}$ Many of those strategies could be adapted to executive-branch settings as well.

It is something of a puzzle, therefore, that the Constitution uses veil rules principally to control legislative action, but not executive or judicial action. One account of this skewed distribution discernible in the literature, although more as an implicit assumption than as an articulated theory, is that veil rules are unnecessary where there are alternative institutionaldesign features that check self-interested decisionmaking. An elegant account of the Bill of Attainder Clause, for example, has it that the Clause enforces legislative impartiality - a condition secured in the adjudicative context by design features such as life tenure, precedent, the ban on ex parte contacts, and so on. "The veil of ignorance in the legislative chambers, in effect, replaces the blindfold on the face of Justice in the courtroom, and creates a different sort of blindness that accomplishes the same sort of effect-a minimal degree of impartiality." 86 This resonates with important constitutional themes, but it supplies only an incomplete rationale for the distribution of veil rules. We would want to know what, on this account, secures impartiality in the executive branch, given that the presumed source of legislative partiality, responsiveness to self-interested factions, is also present in the executive, while the claimed guarantors of judicial

84. Cf. Michael A. Simons, Prosecutorial Discretion and Prosecution Guidelines: A Case Study in Controlling Federalization, 75 N.Y.U. L. REV. 893, 930-36 (2000) (arguing, among other things, that more specific prosecutorial guidelines, by controlling prosecutorial discretion, would prevent unfair treatment of individual defendants).

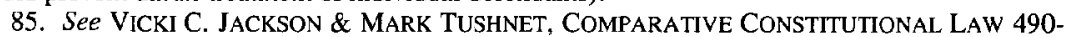
91 (1999) (comparing judicial review mechanisms across judicial systems).

86. Hills, supra note 48, at 242; see also Krent, supra note 35 , at $41,85-90$ (arguing that "legislative retroactivity in the criminal context is more disfavored than lawmaking by judges" because institutional-design features such as life tenure insulate judges from interest-group pressures). 
impartiality are notably absent. Nor can we simply say that the executive and judiciary are both constrained by the obligation to enforce statutes that must themselves be enacted by legislatures subject to pervasive veil constraints. That would leave unexplained the absence of veil rules governing independent, nonexecutory presidential and judicial powers, such as the pardon power and constitutional judicial review.

Perhaps unique institutional-design features of the presidency might be said to promote executive impartiality. Madison argued that groups are more likely to indulge in self-interested decisionmaking than single individuals, since each member of the group incurs only a fractional share of the public opprobrium resulting from the self-interested decision ${ }^{87}$ On this view, perhaps the unitary character of the presidency forces the President to internalize the reputational costs of (visible) self-dealing. But then we would also be entitled to point to unique institutional-design features of the Congress as guarantors of legislative impartiality; examples are bicameralism, long Senate terms, and selection from large districts-all of which Madison argued would dampen self-regarding action by legislative groups. In that case the puzzle would be not why the executive and judiciary are not subject to veil-producing rules, but why the legislature is. The account based on alternative checks against self-interest either leaves unexplained the absence of executive-branch veil rules or else poses the question why veil rules are necessary for any branch.

A different sort of account would invoke the pervasive tradeoff between information and neutrality. In many settings, supplying decisionmakers with more information produces more decisional bias; restricting information in order to reduce bias produces impartial but poorly-informed decisions. The regulatory specialist or expert understands an industry because he worked in it and has lots of friends who still do, while the administrative or judicial generalist who is free of similar biasproducing ties does not understand the subject as well. ${ }^{88} \mathrm{We}$ might trade on this insight in the present context to argue that veil rules are most likely to be found where the costs of poorly-informed decisions are plausibly lower than in settings where veil rules are not found. Perhaps the direct informational costs of throwing veils over congressional decisionmaking are lower than in executive and judicial settings; perhaps the legislature's information will remain in some sense adequate to its tasks even with veil rules in place, while that of other branches will not.

The basic insight is powerful, and it does much to explain why constitutional rules do not impose far more stringent veil strategies than they actually do. A rule delaying the effective date of all legislation for ten

87. The Federalist No. 10, supra note 20, at 125-26 (James Madison).

88. See Levmore, supra note 12, at 2099-2101. 
years, for example, might produce enormous veil effects, yet prove socially disastrous because of the rapid pace of social change; the legislation in effect at any time would have been enacted by the ill-informed legislators of a decade ago. ${ }^{89}$ Indeed, the information-neutrality tradeoff is too powerful an insight, in the sense that it is too general. It might explain any distribution of constitutional veil rules, not just the one we actually have, by assigning the appropriate values to direct information costs; and it might explain any nonconstitutional veil-producing rule or conflict-of-interest rule in the same way. What we need is an account that bites more sharply on the actual Constitution and the distribution of veil rules the Constitution actually embodies.

An account of that sort might point not to the direct (informational) costs of veil rules, but to their indirect and secondary effects on decisionmakers' motivations and activity levels-on what the Framers called institutional "energy." 90 The Framers' simple theory of political psychology described self-interest as the principal spur to action. Impartial reason was normatively superior but practically feeble; the pallid claims of reason could never provoke the same degree of energy and activity as the prospect of selfish gain. A constitutional designer who subscribes to this political psychology might see the distribution of veil rules not only as a direct strategy for checking decisional self-interest, but also as an indirect means for allocating or adjusting energy or activity levels across competing institutions. Holding other factors constant, an individual or institutional decisionmaker subject to a complex of veil rules would predictably undertake fewer projects and make fewer decisions (and fewer selfinterested decisions) than would a decisionmaker enjoying full information about the distribution of benefits and burdens from its decisions. Conversely, the constitutional designer might be reluctant to impose veil rules on an institution intended to display great energy; the price of that energy, more self-interested decisions, would be worth paying in order to secure more projects and activities overall.

All this assumes that the constitutional designer anticipates that decisionmakers possess a measure of control over their agendas and can choose to do more or less, or at least can choose to substitute activity in areas where self-interested action is not constitutionally constrained for activity in areas where self-interested action is constrained. Those assumptions are quite plausible, at least for the legislature and the

89. Cf. ELSTER, supra note 19, at 145 (noting that delaying the effective date of constitutions is "utopian and probably undesirable" because "[d]emands for constitution-making or constitutional revision tend to arise in times of crisis in which waiting is an unaffordable luxury"). 90. See The FEDERALIST No. 70, supra note 20, at 402 (Alexander Hamilton) (discussing "[e]nergy in the executive"). 
executive, and although they do not fit the original judiciary as well, ${ }^{91}$ the constitutional designers of 1787 were deeply influenced by the English model of the executive judiciary (the King's Bench), and thus had only an indistinct grasp of the separation of, or differences between, the executive and judicial departments. ${ }^{92}$ Another wrinkle is that, strictly speaking, not just veil rules but any rule or institutional arrangement that constrains selfinterest relative to other motives would have an energy-dampening effect. But the other rules and arrangements I have discussed-conflict-of-interest rules, on one hand, and the separation of powers, on the other-do not have any differential effect on energy across institutions. That is contingently true of conflict-of-interest rules, because there are too few of them in the Constitution to have any empirically important effect, differential or otherwise, ${ }^{93}$ and it is definitionally true of the separation of powers, which has an identical effect on all institutional competitors.

On this picture, the skewed distribution of veil rules in the Constitution-with legislative action heavily veiled and presidential action veiled hardly at all-indirectly encourages executive activity relative to legislative activity, even if the price is that a greater fraction of executive than of legislative activity will be self-interested. As an originalist matter, this rationale accords well with many of the Framers' principal aims in constitutional design. The story is familiar. The excesses of populist legislatures in the period of the Articles of Confederation caused the Framers to regard legislatures as the " most dangerous branch"; the one that was most likely to usurp the powers of other branches, disturb vested property rights, and in general provide scope for unrestrained factionalism. Perhaps Madison's central concern, both during the Convention and in the ratification debates, was to dampen the "restless energy" of faction-driven legislatures, and we may interpret veil rules as devices for suppressing that energy by removing the impetus of self-interest. To be sure, as previously

91. The modern federal judiciary has developed a great deal of control over its own agenda through such devices as standing and justiciability rules, see, e.g., Ashwander v. Tenn. Valley Auth., 297 U.S. 288, 341 (1936) (Brandeis, J., concurring), doctrines of equitable restraint, see, e.g., Younger v. Harris, 401 U.S. 37, $48-50$ (1971), and the development of discretionary certiorari. But it should be noted that quite early in its history, the federal judiciary moved to assert control over its activities. See, e.g., Hayburn's Case, 2 U.S. (2 Dall.) 408, 410 n.a (1792) (listing circuit court opinions declining to give Congress and the Secretary of War nonbinding opinions on pension applications).

92. David F. EPSTEIN, THE POLITICAL THEORY OF THE FEDERALIST 186 (1984) (noting that Locke and Hamilton spoke of the judicial power as a component of the executive power).

93. There are only a handful of conflict-of-interest rules in the Constitution. In addition to the previously discussed provision that bars the Vice President from presiding over a Senate impeachment trial of the President, see supra note 28, other examples are Article I, Section 9, Clause 8, which bars officeholders from accepting foreign gifts or titles without the consent of Congress; Article II, Section 1, Clause 2, which prohibits members of Congress and federal officers from serving in the Electoral College; and Article II, Section 1, Clause 7, which bars the President from accepting any emolument from the states during his term in office. 
discussed, Madison's principal strategy for checking self-interest was the institutional competition arising in a system of separated powers. But it is noteworthy that when Madison sought to justify the constitutional requirements of prospectivity and generality embodied in the Ex Post Facto and Bill of Attainder Clauses, his defense sounded precisely in this concern about the activity-dampening effects of veil rules:

Bills of attainder, ex post facto laws, and laws impairing the obligation of contracts, are contrary to the first principles of the social compact and to every principle of sound legislation. ... The sober people of America are weary of the fluctuating policy which has directed the public councils. They have seen with regret and indignation that sudden changes and legislative interferences, in cases affecting personal rights, become jobs in the hands of enterprising and influential speculators, and snares to the more industrious and less informed part of the community. They have seen, too, that one legislative interference is but the first link of a long chain of repetitions, every subsequent interference being naturally produced by the effects of the preceding. ${ }^{94}$

Madison's point here is not that enactments by legislative factions free to implement self-interested plans are necessarily substantively bad enactments (although we have other grounds for inferring that he held that view as well). Rather, the argument is that excessive legislative activity taken under the spur of self-interest produces instability that is socially damaging independent of the content of enactments. Self-interested factions will change property and contract rules too frequently, retarding productive investments and long-term commercial planning. Prospectivity and generality would dampen legislative turbulence and "give a regular course to the business of society." 95 The concern for property and settled expectations is why Madison ties prospectivity and generality to the Contracts Clause; although the Supreme Court has today largely abandoned that link, the specific character of the harm flowing from excessive levels of legislative activity is essential to the theory.

Conversely, the Framers hoped to imbue the executive branch with the "vigor" it lacked in state constitutions built around legislative supremacy. Hamilton's series of essays on the presidency has as its guiding thread the premise that "[e]nergy in the executive is a leading character in the definition of good government," energy that Hamilton contrasts with the "deliberation and wisdom" that a (suitably impartial) legislature would display. ${ }^{96}$ Far from wishing to devise rules that would suppress self-

94. ThE FEDERALIST No. 44, supra note 20, at 287-88 (James Madison).

95. Id. at 288 .

96. See The Federalist No. 70, supra note 20, at 402-03 (Alexander Hamilton). 
interested motives for presidential action, Hamilton argued for structuring the office in ways that would encourage the President's personal interest in and attachment to his station and the exercise of its powers. That personal interest would in turn supply the President with a motive to govern actively, to undertake publicly beneficial projects (from which a unitary executive would reap all the reputational gains), and to resist legislative encroachments. ${ }^{97}$ By combining self-interest with opportunity, precisely the combination that veil rules prevent through their effects on information, the Framers hoped to promote executive activity of the very sort that they sought to discourage in legislatures.

The foregoing is an interpretive account of the constitutional distribution of veil rules on textualist and originalist premises. On nontextualist and nonoriginalist premises, or simply as a matter of normative constitutional design, the current distribution of veil rules might appear skewed in precisely the wrong direction. In a century of presidential government under broad delegations of lawmaking authority, one might prefer to "interpret" the Constitution's commitments, or simply to change its rules, to subject (some) executive decisionmaking to (some of) the same veil rules. That is not my topic here. I simply note that one should not overlook structural or framework legislation of quasi-constitutional stature that has already done much of the work. One might, for example, understand the Administrative Procedure Act as, in important part, an attempt to subject agency decisionmaking to the norms of generality and prospectivity associated with veil rules-here in the form of substantive prohibitions on arbitrary administrative treatment of like cases $^{98}$ and interpretive canons that restrict agency power to make law retroactively. ${ }^{99}$

\section{CONCLUSION}

The localized literatures on particular constitutional provisions and doctrines are replete with passing references to the "veil of ignorance." My project here has been to synthesize and critique these claims in order to provide an overview of an important theme in constitutional design, to unpack the mechanisms by which central constitutional clauses generate veil of ignorance effects, and to provide an account of the skewed distribution of these veil rules across the Constitution. Further extensions of the project might extend the inquiry laterally to take account of comparative constitutionalism more systematically than I have done here, or might

97. See THE FEDERALIST NO. 71 (Alexander Hamilton) (arguing for four-year presidential terms on this basis).

98. See Citizens To Preserve Overton Park, Inc. v. Volpe, 401 U.S. 402, 416 (1971).

99. See Bowen v. Georgetown Univ. Hosp., 488 U.S. 204, 208-09 (1988) (stating that agencies may make retroactive rules only under clear statutory authorization). 
extend it chronologically to take account of the law's adaptation to a constitution that deploys the veil of ignorance strategy in such a lopsided way. Whether or not the particulars of the theory are persuasive, however, the important point is that the idea of the veil of ignorance at least supplies a useful lens through which to appreciate the complexities of constitutional design. 
